\title{
Microarray analysis of a pyrethroid resistant African malaria vector, Anopheles funestus, from southern Africa
}

\author{
R. N. Christian ${ }^{a b}$, C. Strode ${ }^{c}$, H. Ranson ${ }^{c}$, N. Coetzer ${ }^{\text {d }}$, M. Coetzee ${ }^{\text {ab }}$ and L. L. \\ Koekemoer $^{\text {ab }}$
}

\begin{abstract}
${ }^{a}$ Vector Control Reference Unit, National Institute for Communicable Diseases, National Health Laboratory Service, Private Bag X4, Sandringham, Johannesburg 2131, South Africa.

${ }^{b}$ Malaria Entomology Research Unit, School of Pathology, Faculty of Health Sciences, University of the Witwatersrand, Johannesburg, South Africa.

${ }^{c}$ Vector Research Group, Liverpool School of Tropical Medicine, Liverpool, United Kingdom.

${ }^{\mathrm{d}}$ ACGT Computational Biology and Bioinformatics Unit, Department of Biochemistry, University of Pretoria, South Africa.
\end{abstract}

\author{
Email addresses: \\ R. N. Christian: Riannc@nicd.ac.za \\ C. Strode: C.Strode@liverpool.ac.uk \\ H. Ranson: hranson@liverpool.ac.uk \\ N. Coetzer: nanette.coetzer@gmail.com \\ M. Coetzee: Maureenc@nicd.ac.za \\ L. L. Koekemoer: Lizettek@nicd.ac.za
}

Correspondence: Riann Christian. Vector Control Reference Unit, National Institute for Communicable Diseases, National Health Laboratory Service, Private Bag X4, Sandringham, Johannesburg 2131, South Africa. Telephone: +27 118855365 . Fax: +27 113866485 . 


\begin{abstract}
Anopheles funestus is one of the major malaria vectors in southern Africa and several populations in this region are resistant to pyrethroids. The current study uses a microarray based approach to identify genes up-regulated in the pyrethroid resistant population, FUMOZ, from Mozambique. As the full set of detoxification genes in An. funestus are unknown, this study investigated the utility of the An. gambiae 'detox chip' to screen for differentially expressed detoxification genes in An. funestus. Differential expression of detoxification genes in three day old adult females and males from the FUMOZ resistant strain and the FANG susceptible strain was identified using the An. gambiae 'detox chip'. After optimization of the hybridization conditions, over $90 \%$ of the probes showed a positive signal. Only three genes were significantly $(p<0.001)$ differentially expressed in the females, CYP6P9 (5.4-fold), COI (2.7-fold) and CYP6M7 (1.8-fold). The same genes were also significantly differentially expressed in the adult males, CYP6P9 (6.0-fold), COI (2.9-fold) and CYP6M3 (3.6-fold) together with an additional 21 transcripts. Quantitative PCR (qPCR) analysis was conducted to validate the microarray results. This study demonstrated that heterologous hybridization is a helpful tool in identifying detoxification genes differentially expressed in An. funestus strains.
\end{abstract}

\title{
Keywords:
}

Microarrays, An. funestus, 'detox chip', pyrethroid resistance, cytochrome P450. 


\section{Introduction}

In 2008 the World Health Organization [1] reported that an estimated 247 million people are affected worldwide with malaria. Most malaria deaths occur in Africa and this situation results from both the epidemiological situation in Africa and limited control activities during the past decades. The lack of adequate health services often results in deficiencies in treatment and this is compounded by increasing drug resistance [2]. Insecticide resistance in the mosquito vectors is increasingly impacting on malaria control interventions [3; 4]. Malaria control in southern Africa is largely based on the use of insecticide treated bed nets (ITNs) or indoor residual spraying (IRS) with pyrethroids being the insecticides of choice. There have been reports of insecticide resistance in malaria vectors in southern Africa and these include DDT and pyrethroid resistance in Anopheles arabiensis in South Africa [5;6] and An. funestus resistant to pyrethroids and carbamates in South Africa and Mozambique $[7 ; 8]$. The development of pyrethroid resistance in An. funestus resulted in a malaria outbreak in South Africa between 1996 and 2000 [7].

Two major resistance mechanisms are largely responsible for insecticide resistance i.e. target-site resistance and metabolic resistance [9]. To date there have been no reports of target site resistance to pyrethroids in An. funestus. Metabolic resistance is characterized by increased activity of detoxifying enzymes such as esterases, cytochrome P450 monooxygenases and glutathione-S-transferases (GSTs) [9;10]. All three enzyme groups are encoded by large gene families and identifying the individual genes associated with resistance is a very laborious exercise. This task was facilitated for An. gambiae by the 
development of a custom microarray specifically designed to detect transcription variation in genes associated with insecticide resistance [11]. This array was named the ‘detoxification chip' (detox chip'). The ‘detox chip' has been utilized for screening $A n$. gambiae populations from Kenya and Zanzibar [11], Benin [12], Nigeria [13] and Ghana $[14 ; 15]$ and has also been successfully used for An. arabiensis from Cameroon [16] and An. stephensi from Dubai [17].

Biochemical assays and synergists have been used previously to characterize the resistance mechanisms in the FUMOZ-R pyrethroid resistant strain from Mozambique [8]. These studies implicated elevated cytochrome P450 activity as the main mechanism. This was later supported by qPCR [18] and genetic mapping studies [19] which both identified the P450 gene, CYP6P9, as being highly over-expressed in the resistant FUMOZ-R strain.

In this study we investigated the use of the An. gambiae 'detox chip' in determining potential genes associated with insecticide resistance in a southern African An. funestus resistant strain (FUMOZ-R) and a susceptible strain (FANG). Selected significantly overexpressed genes from the microarray results were validated using qPCR. 


\section{Materials and methods}

\subsection{Mosquito strains}

Two An. funestus strains were used in this study. The FUMOZ-R strain originated from Mozambique and has been maintained under selection pressure with permethrin. FANG originates from Angola and is susceptible to all known insecticides. Details on the insecticide resistance status of these colonies can be found in the study by Hunt et al. [20]. Both strains are maintained in standard insectary conditions of $25^{\circ} \mathrm{C}$ with $80 \%$ relative humidity and $12 \mathrm{~h}$ day/night, $45 \mathrm{~min}$ dusk/dawn lighting cycle.

\subsection{Sample preparation and microarray hybridizations}

Female and male An. funestus adults were separated on day of emergence and fed on $10 \%$ sugar solution until they were three days old (without prior exposure to pyrethroids). The transcription levels in the three day old resistant FUMOZ-R adult females were compared to the susceptible females of the same age. The same was done for the males. Each comparison in all experiments consisted of three independent biological replicates and two technical repeats which included dye swaps to control for dye bias. There were four within-array replicate spots per microarray slide. Total RNA was extracted from three batches of fifteen three day old adult females or males using the PicoPure ${ }^{\mathrm{TM}}$ RNA Isolation kit (Arcturus) according to manufacturer's instructions. Amplified mRNA (amRNA) was synthesized using the RiboAmp ${ }^{\mathrm{TM}}$ RNA Amplification Kit (Arcturus) according to manufacturer's instructions. amRNA was measured using the Nanodrop spectrophotometer (Nanodrop Technologies, Wilmington, USA) and the quality of the RNA was assessed on a $0.8 \%$ gel. 
The RNA and primer mix consisting of $8 \mu \mathrm{g}$ of amRNA for each of the samples $2 \mu 1$ mRNA spike mix (Universal Lucidea Scorecard, Amersham), random hexamers (Invitrogen) and water was incubated for 5 minutes at $70^{\circ} \mathrm{C}$. The RNAs mix were reverse transcribed into Cy-labeled cDNAs using Cy3 or Cy5-dUTPs (Amersham), DTT, dTNTPs, RNAsin and Superscript III (Invitrogen). The samples were incubated at $50^{\circ} \mathrm{C}$ for $21 / 2$ hours. A mixture of $1 \mathrm{M} \mathrm{NaOH} / 20 \mathrm{mM}$ EDTA was added to the labeled cDNAs to stop the reaction. The Cy-labeled cDNAs that were to be hybridized together were pooled and purified using the Cyscribe ${ }^{\mathrm{TM}} \mathrm{GFX}^{\mathrm{TM}}$ Purification kit (Amersham). The concentration of the cDNAs and the binding efficiencies of the Cy-dyes were determined using the Nanodrop spectrophotometer (Nanodrop Technologies, Wilmington, USA). Samples that had a low cDNA yield $(<15 \mathrm{ng} / \mu \mathrm{l})$ and poor dye incorporation $(<0.1 \mathrm{pmol} / \mu 1$ of each dye $)$ were discarded. $5 \mu \mathrm{g}$ of poly $\mathrm{dA}$ oligo (Amersham Biosciences) were added to the purified targets to reduce nonspecific hybridization. The labeled samples were dried in a speed vacuum centrifuge for 1 hour at $30^{\circ} \mathrm{C}$ and re-suspended in $15.5 \mu 1$ of hybridization buffer (Corning). The targets were denatured by incubation at $95^{\circ} \mathrm{C}$ for 5 minutes. The An. gambiae 'detox chip' was pre-treated using the Universal Hybridization kit (Corning), according to manufacturer's instructions. However the wash solutions were made up using three times the amount of components as stated in the protocol by David et al. (2005). The target mix was added to the microarray chip and hybridizations were performed at $38^{\circ} \mathrm{C}$ for 16 hours.

After the incubation the slides were washed using the Universal Hybridization kit (Corning). The slides were pre-soaked in wash solution 1 for one to two minutes at $38^{\circ} \mathrm{C}$, 
followed by a second wash of solution 1 for $2 \frac{1}{2}$ minutes and finally incubated in wash solution 2 at ambient temperature for 5 minutes. The slides were subjected to three washes in fresh wash solution 3 at ambient temperature for one minute. Excess wash solution was removed from the slides by centrifugation at $2500 \mathrm{rpm}$ for two minutes.

\subsection{Microarray scanning and data analysis}

The slides were scanned using the Genepix 4000B scanner (Molecular Devices, USA), where the PMT values were adjusted to give a ratio of $1 / 1$. The quality of spots and background intensities were examined and corrected using the Genepix Pro 6.0 software (Axon instruments, USA).

The raw intensity values were analyzed using the limma software package version 2.12.0, from the BioConductor project, in the R programming environment [21]. Image plots were generated to inspect the variation of background values across the arrays. Background correction was carried out using the 'normexp' method [22] with an offset of 50. Within array normalization was performed, using the 'control' method in limma to fit a global loess curve through a set of non-differentially expressed control spots. This curve was applied to all the other spots, thereby normalizing the M-values for each array separately [23]. Between array normalization was performed using the 'Aquantile' method to ensure that the A values have the same empirical distribution across arrays. To visualize the effect of normalization, MA-plots were used. The limma package uses empirical Bayes analysis to assess differential expression, by calculating a $B$-statistic, a moderated $t$-statistic and an adjusted $p$-value for each gene [24]. A top table was 
generated which revealed the highly differentially expressed genes for both the strains of interest. Genes exhibiting adjusted $p$-values $<0.001$ and fold-changes $\geq 1.5$ were considered as statistically significant over-expressed genes. The data was deposited into the vectorbase database (https://www.vectorbase.org).

\subsection{Quantitative Real Time PCR ( $q P C R)$}

Quantitative PCR analysis was carried out on three day old FUMOZ-R and FANG females and males to verify the results obtained from the microarray experiments. qPCR was only carried out on the three up-regulated genes in the females, and the same was done for the males. The remaining up-regulated genes in the males will be carried out in future studies. Primers were designed for genes CYP6M7 and COI. The primer pair used for the CYP6P9 gene was a gene-specific primer set [25] subsequent to the discovery of a duplicate gene, CYP6P13 [26]. The cDNA probe sequence was aligned to both the CYP6P13 (GenBank accession number: EF152577) and CYP6P9 (GenBank accession number: EU450763) gene. The cDNA probe on the microarray slide had a $81 \%$ sequence identity to both $C Y P 6 P 9$ and $C Y P 6 P 13$. Due to sequences similarities between $C Y P 6 P 9$ and CYP6P13, gene-specific primers were used for both CYP6P13 and CYP6P9.

\subsubsection{RNA Isolation}

The RNA samples obtained from the extractions used in the microarray experiments were used for the qPCR part of the study. The samples were quantified using a Nanodrop ${ }^{\circledR}$ Spectrophotometer (Nanodrop Technologies, Wilmington, DE, USA). 


\subsection{2. $c D N A$ synthesis}

Total RNA was converted to cDNA using the High Capacity RNA-to-cDNA kit (Applied Biosystems, 4387406). The quality and quantity of cDNA was measured using the Nanodrop ${ }^{\circledR}$ Spectrophotometer (Nanodrop Technologies, Wilmington, DE, USA) and the cDNA samples were stored at $-70^{\circ} \mathrm{C}$ until further use.

\subsubsection{Primer Design}

Primer sequences for $C Y P 6 P 9$ and CYP6P13 were obtained from the Christian et al. [25] study. Primers were designed for the CYP6M7 (Accession number: AY729660.1) and COI (Accession number: AY423059.1) genes using the An. funestus gene sequences. These primers were designed using Beacon Designer 3.0 software (Biorad, Hercules, CA, USA). The $r s p 7$ (EF450776) primers was used as a reference gene to normalize data. Two different sets of primers were designed for the CYP6M7 gene (Table 1). However amplification of the product was unsuccessful after numerous attempts to optimize the cycling conditions, primer and cDNA concentrations.

\subsubsection{Quantification of CYP6P9, CYP6P13, CYP6M7 and COI}

The qPCR experiments were performed using the Bio-Rad CFX96 ${ }^{\mathrm{TM}}$ Real-Time PCR Detection System (Bio-Rad, Hercules, CA, USA). A total volume of $25 \mu 1$ containing 12.5 $\mu 1 \mathrm{IQ}^{\mathrm{TM}}$ SYBR supermix (Bio-Rad, 1708882), $4 \mu 1$ primer $(2.5 \mu \mathrm{M}), 1 \mu \mathrm{l}$ cDNA (50ng) was used per reaction. A 2-fold serial dilution of cDNA was used for the standard curve reaction. Serial dilutions of cDNA for the standard curve were prepared. 
Table 1 Primers used in Quantitative PCR (qPCR).

\begin{tabular}{|c|c|c|c|c|}
\hline Gene & Primer Sequence & $\begin{array}{l}\text { Fragment Length } \\
\text { (bp) }\end{array}$ & $\begin{array}{l}\text { qPCR Annealing/Detection } \\
\text { Temp }\left({ }^{\circ} \mathrm{C}\right)\end{array}$ & Reference \\
\hline COI & $\begin{array}{ll}\text { Fwd } & \text { 5' } \\
\text { Rev } & \text { 5' AAT GAG CAG GAA CAG GAT GAA CAG 3' } \\
\text { ', AA AAG CAC CAG CAT GAG 3' }\end{array}$ & 75 & $59.40 / 79.00$ & This paper \\
\hline CYP6M7 & $\begin{array}{l}\text { Fwd1 5'GAA GTG CTG GAA CGT CAT AAC 3' } \\
\text { Rev1 5' CGG ATA TTT ACG CAG GCT TTC 3' } \\
\\
\text { Fwd2 5', TCA GAT TCC GAA AGA AAG C 3' } \\
\text { Rev2 5' ATC ACG ATG AAT CGC ATA C 3' }\end{array}$ & $*$ & * & This paper \\
\hline СYР6P9 & $\begin{array}{l}\text { Fwd 5' AGA TGT GAT TGG CAC CTG T C 3' } \\
\text { Rev 5' TCG ATA TTC CAC CGT TTC CT 3' }\end{array}$ & 232 & $55 / 82.00$ & $\begin{array}{l}\text { Christian et al., } \\
2010\end{array}$ \\
\hline CYP6P13 & $\begin{array}{l}\text { Fwd 5', CTG GAT CTC CTA ATT ATG ATG AAG TTT TTC 3' } \\
\text { Rev 5' GTT CAC CGT CTC GCG GAC T 3, }\end{array}$ & 132 & $59.1 / 81.00$ & $\begin{array}{l}\text { Christian et al., } \\
2010\end{array}$ \\
\hline$r s p 7$ & $\begin{array}{l}\text { Fwd 5' TTA CTG CTG TGT ACG ATG CC 3' } \\
\text { Rev 5' GAT GGT GGT CTG CTG GTT C 3' }\end{array}$ & 135 & $* * / 85.50$ & $\begin{array}{l}\text { Amenya et al., } \\
2008\end{array}$ \\
\hline
\end{tabular}

* No amplification.

** Annealing temperature for the rsp 7 gene is equivalent to the respective genes. 
The cycling conditions for each primer set are presented in Table 1. Each biological sample was repeated three times on a plate. Three biological repeats were done on different days. The data was analyzed using the relative quantification method [27].

\section{Results}

A previous study [25] has shown that both females and males from the resistant strain, FUMOZ-R, are resistant to permethrin, although mortality rates varied between the two sexes. Therefore gene expression was determined in both three day old adult females and males of the An. funestus FUMOZ-R (resistant) and FANG (susceptible) strains using the An. gambiae 'detox chip'. Minor adjustments to the original protocol were made in order to maximize hybridization of the targets to the chip. The hybridization temperature was reduced from $42^{\circ} \mathrm{C}$ to $38^{\circ} \mathrm{C}$ and lower stringency wash buffers and shorter washing times were used. These optimized conditions were similar to those used for cross-species hybridization to An. stephensi [17]. After optimization of the hybridization conditions over $90 \%$ of the spots on the slide were detected as opposed to $55 \%$ obtained when using the more stringent original hybridization conditions described by David et al. [11]. The percentage of probes detected was obtained by manually counting the number of fluorescent spots on the slides after hybridization.

Genes were considered to be differentially expressed if they demonstrated a $\geq 1.5$-fold change in expression between the two strains and a $p$-value of $<0.001$ over the entire experiment. Out of a total of 254 gene probes on the An. gambiae 'detox chip', $1.18 \%$ of

genes were significantly differentially expressed in the females as opposed to $9.45 \%$ in 
Table 2 List of genes differentially expressed in females and males of the resistant An. funestus strain, FUMOZ-R. Gene names provided in table are as per An. gambiae naming, except for those where the An. funestus specific name has been identified (Amenya et al. 2005) which appears in brackets behind An. gambiae names.

\begin{tabular}{|c|c|c|c|c|}
\hline Gene Name & Group & $\begin{array}{l}\text { Vectorbase Accession } \\
\text { Number }\end{array}$ & $\begin{array}{l}\text { Fold } \\
\text { Change }\end{array}$ & Adj. P-value \\
\hline \multicolumn{5}{|l|}{ Females } \\
\hline $\begin{array}{l}\text { CYP6P3 } \\
(C Y P 6 P 9)\end{array}$ & Cytochrome P450 & $\underline{\text { AGAP002865 }}$ & 5.4 & $2.84 \times 10^{-07}$ \\
\hline $\mathrm{COI}$ & $\begin{array}{l}\text { Cytochrome } \\
\text { oxidase I }\end{array}$ & DQ465331 (GB) & 2.7 & $5.11 \times 10^{-06}$ \\
\hline $\begin{array}{l}\text { CYP6M3 } \\
(\text { (СYP6M7) }\end{array}$ & Cytochrome P450 & AGAP008213 & 1.8 & $8.82 \times 10^{-04}$ \\
\hline \multicolumn{5}{|l|}{ Males } \\
\hline $\begin{array}{l}\text { CYP6P3 } \\
\text { (СYP6P9) }\end{array}$ & Cytochrome P450 & AGAP002865 & 6.0 & $3.99 \times 10^{-14}$ \\
\hline $\begin{array}{l}\text { CYP6M3 } \\
\text { (CYP6M7) }\end{array}$ & Cytochrome P450 & AGAP008213 & 3.6 & $4.13 \times 10^{-08}$ \\
\hline $\begin{array}{l}\text { CYP6M2 } \\
\text { (СYР6M8) }\end{array}$ & Cytochrome P450 & $\underline{\text { AGAP008212 }}$ & 3.0 & $8.46 \times 10^{-09}$ \\
\hline COI & $\begin{array}{l}\text { Cytochrome } \\
\text { oxidase I }\end{array}$ & $\underline{\mathrm{DQ} 465331(\mathrm{~GB})}$ & 2.9 & $5.21 \times 10^{-12}$ \\
\hline SOD2 & $\begin{array}{l}\text { Superoxide } \\
\text { dismutase }\end{array}$ & AGAP005234 & 2.5 & $2.7 \times 10^{-06}$ \\
\hline GSTS1-1 & $\begin{array}{l}\text { Glutathione S- } \\
\text { transferase }\end{array}$ & $\underline{\text { AGAP010404 }}$ & 2.5 & $5.21 \times 10^{-12}$ \\
\hline$T R X I$ & Thioredoxin & AGAP009584 & 2.4 & $6.74 \times 10^{-04}$ \\
\hline Actincytopl & Actin & TIGR: TC48694 & 2.3 & $5.96 \times 10^{-04}$ \\
\hline CYP6R1 & Cytochrome P450 & AGAP008205 & 2.2 & $1.30 \times 10^{-06}$ \\
\hline$T R X 3$ & Thioredoxin & AGAP003338 & 2.2 & $6.74 \times 10^{-04}$ \\
\hline Cytochrome C & Cytochrome C & $\overline{\text { AGAP009537 }}$ & 2.2 & $1.06 \times 10^{-07}$ \\
\hline CYP12f2 & Cytochrome P450 & AGAP008021 & 2.2 & $2.92 \times 10^{-04}$ \\
\hline CYP6AG1 & Cytochrome P450 & AY745223(GB) & 2.0 & $1.36 \times 10^{-04}$ \\
\hline $\begin{array}{l}\text { CYP9J5 } \\
\text { (СYP9J11) }\end{array}$ & Cytochrome P450 & AGAP012296 & 2.0 & $6.54 \times 10^{-06}$ \\
\hline MnSODI & $\begin{array}{l}\text { Superoxide } \\
\text { dismutase }\end{array}$ & $\underline{\text { AGAP010517 }}$ & 2.0 & $2.30 \times 10^{-05}$ \\
\hline SP8898 & Serine protease & AGAP003642 & 1.9 & $2.73 \times 10^{-04}$ \\
\hline CYP9M1 & Cytochrome P450 & AGAP009374 & 1.8 & $4.73 \times 10^{-05}$ \\
\hline GSTS1-2 & $\begin{array}{l}\text { Glutathione S- } \\
\text { transferase }\end{array}$ & AF513639(GB) & 1.7 & $6.74 \times 10^{-04}$ \\
\hline CYP6Z1 & Cytochrome P450 & AGAP008219 & 1.7 & $1.30 \times 10^{-06}$ \\
\hline CYP6AG2 & Cytochrome P450 & AY745224 (GB) & 1.6 & $8.50 \times 10^{-04}$ \\
\hline GSTMS3 & $\begin{array}{l}\text { Glutathione S- } \\
\text { transferase }\end{array}$ & AGAP009946 & 1.6 & $1.01 \times 10^{-03}$ \\
\hline $\begin{array}{l}\text { CYP6M1 } \\
\text { (CYP6M1) }\end{array}$ & Cytochrome P450 & AGAP008209 & 1.6 & $5.96 \times 10^{-04}$ \\
\hline GSTD2 & $\begin{array}{l}\text { Glutathione S- } \\
\text { transferase }\end{array}$ & $\underline{\text { AGAP004165 }}$ & 1.6 & $3.18 \times 10^{-05}$ \\
\hline $\begin{array}{l}\text { CYP9J3 } \\
\text { (CYP9J12) }\end{array}$ & Cytochrome P450 & $\underline{\text { AGAP012291 }}$ & 1.5 & $7.71 \times 10^{-04}$ \\
\hline
\end{tabular}


males. No genes were found to be over-expressed in both females and males from the susceptible An. funestus, FANG, strain. In the resistant An. funestus FUMOZ-R stain, however, three genes were differentially expressed in the females (Figure 1). The gene with the highest fold change in expression in the females was a cytochrome P450 gene CYP6P9 (CYP6P3 orthologous gene in An. gambiae) (5.4-fold) (Table 2). The cytochrome oxidase I gene, $\mathrm{COI}$, was 2.7 -fold differentially expressed and the third gene also a member of the cytochrome P450 enzyme family, CYP6M7 (CYP6M3 orthologous gene in An. gambiae) was 1.8-fold differentially expressed.

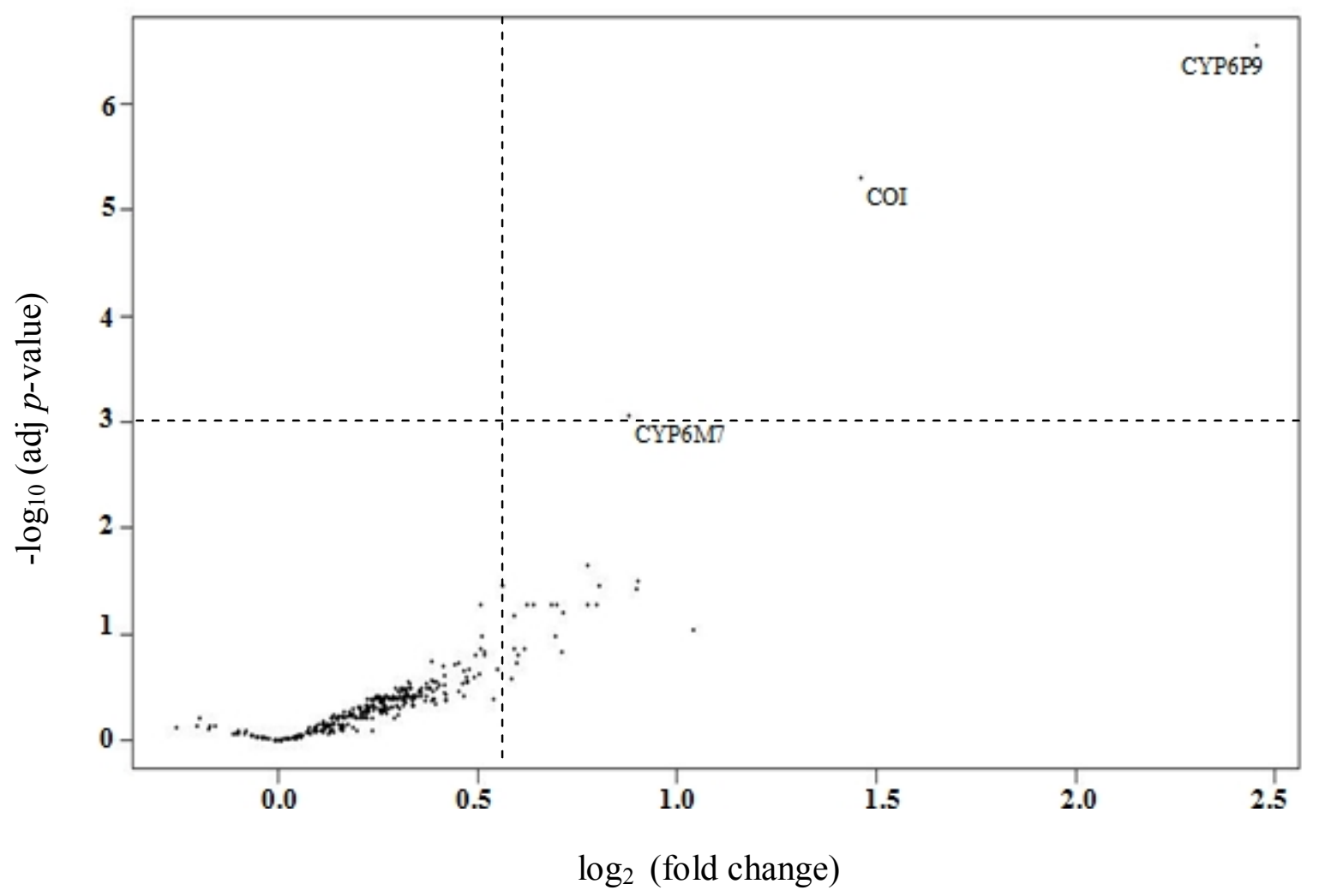

Figure 1 Volcano plot representing genes differentially expressed in females of the An. funestus strain, FUMOZ-R.

The horizontal line represents the cut off for the level of significance $\alpha=0.001$ and vertical lines indicate cut off for the 1.5 -fold change threshold. 
A total of 24 genes were significantly differentially expressed in males from the resistant FUMOZ-R strain (Table 2). Fifty percent of these genes $(n=12)$ belonged to the cytochrome P450 enzyme group, $17 \%(n=4)$ to the glutathione-S-transferase, $8 \%(n=2)$ to the Copper-Zinc $(\mathrm{Cu}-\mathrm{Zn})$ superoxide dismutase, $8 \%(\mathrm{n}=2)$ to the thioredoxin group and the remaining $17 \%(n=4)$ to other groups. Three genes that were differentially expressed and common to both sexes include the cytochrome P450 genes, CYP6P9 (6.0-fold), CYP6M7 (3.6-fold) and cytochrome oxidase I, COI (2.9-fold) (Figure 2). Other differentially expressed genes in the males are shown in Table 2.

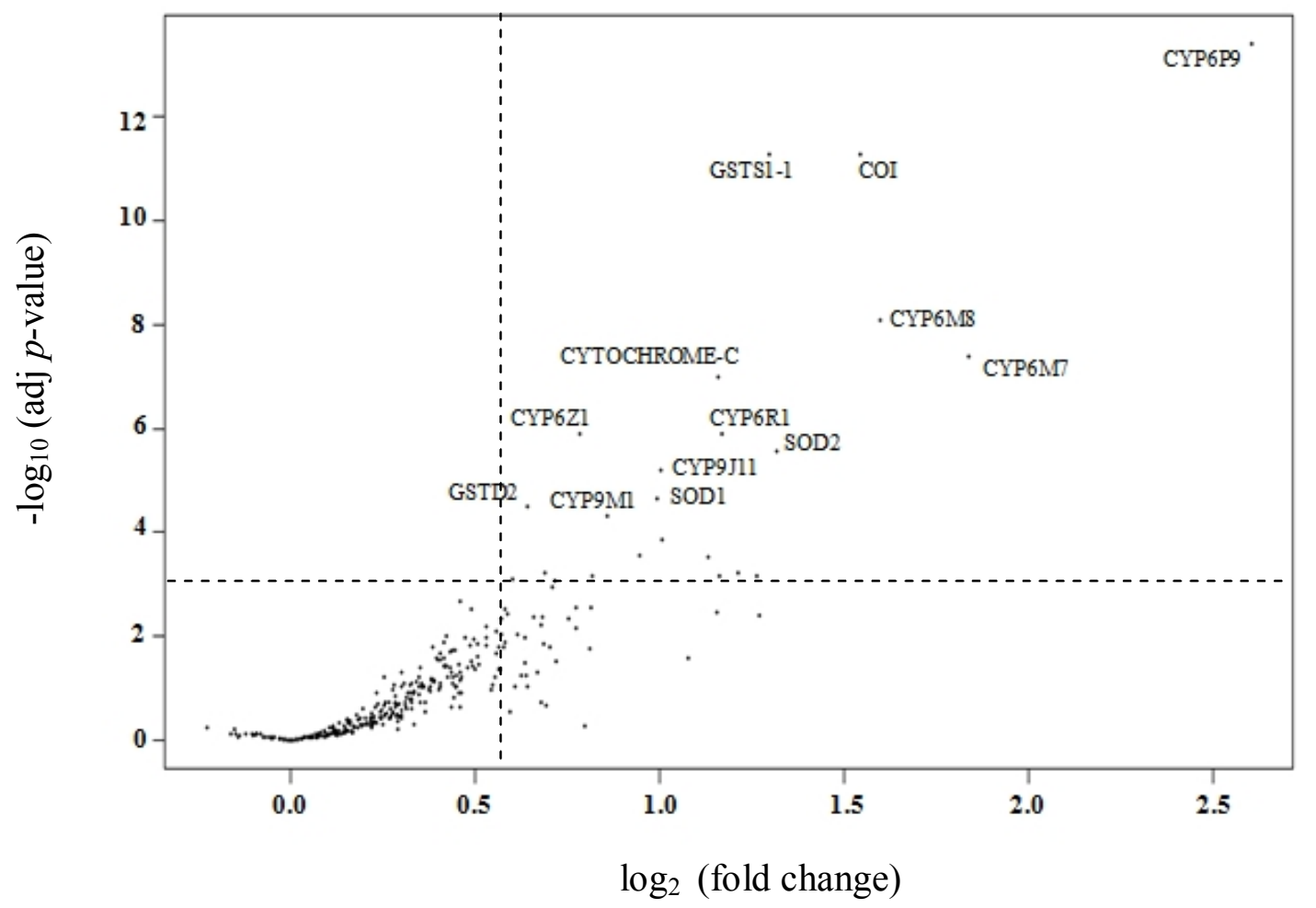

Figure 2 Volcano plot representing genes differentially expressed in males of the An. funestus strain, FUMOZ-R.

The horizontal line represents the cut off for the level of significance $\alpha=0.001$ and vertical lines indicate cut off for the 1.5 -fold change threshold. 
Out of a total of 254 genes on the An. gambiae 'detox chip', 18 probes failed to produce any signal on the array (Table 3). Five of these genes, CYP306A1, CYP6P4, CYP4C28, CYP305A3, and CYP6Z2 belonged to the cytochrome P450 group. Only two genes belonged to the GST group, GSTD4 and GSTD3 and the peroxidase (HPX) group, HPX7 and HPX5A. However a large number of genes that did not bind to the microarray slide belonged to the carboxylesterase group. These include COEAE1G, COEJHE1E, COEunkn, COEAE1F, COEAE7G, COEBE2O and COEBE4C. The remaining genes were superoxidase dismutase $(S O D 3 B)$ and the serine protease gene $(S P 21408)$.

Some sequence data for detoxification genes is available for An. funestus [18] enabling the degree of identity between the An. gambiae probes and their putative An. funestus orthologs to be determined. The probe sequences of the genes on the An. gambiae 'detox chip' were aligned against the known An. funestus sequences. The percentage identities were calculated for genes COI, CYP6M1, CYP6M8, CYP6P4, CYP9J11, CYP9J12, CYP6P9 and CYP6M7 (Table 4). All genes had a percentage similarity of $>40 \%$. The genes with the highest percentage similarity were genes CYP6P9 (81\%), CYP6P13 (81\%), CYP6M1 (79.4\%) and CYP6P4 (75.0\%). Surprisingly no signal was detected for CYP6P4 despite the $75 \%$ sequence similarity between the two species.

The low level of sequence identity between some of the probes and their putative target genes in An. funestus suggests that some care should be taken in the interpretation of the results, particularly given the high level of sequence identity between some detoxification genes in the same species [18]. The possibility that the microarray results are confounded 
Table 3 List of genes that did not hybridize onto the An. gambiae 'detox chip' in both the females and males of the resistant and susceptible An. funestus strain, FUMOZ-R and FANG.

\begin{tabular}{|l|l|l|}
\hline Gene Name & Group & $\begin{array}{l}\text { Vectorbase accession } \\
\text { number }\end{array}$ \\
\hline CYP306A1 & Cytochrome P450 & $\underline{\text { AGAP004665 }}$ \\
\hline CYP6P4 & Cytochrome P450 & $\underline{\text { AGAP002867 }}$ \\
\hline CYP4C28 & Cytochrome P450 & $\underline{\text { AGAP010414 }}$ \\
\hline CYP305A3 & Cytochrome P450 & $\underline{\text { AGAP005657 }}$ \\
\hline CYP6Z2 & Cytochrome P450 & $\underline{\text { AGAP008218 }}$ \\
\hline SOD3B & Superoxide dismutase & $\underline{\text { AGAP010347 }}$ \\
\hline GSTD4 & $\begin{array}{l}\text { Glutathione S- } \\
\text { transferase }\end{array}$ & $\underline{\text { AGAP004381 }}$ \\
\hline GSTD3 & $\begin{array}{l}\text { Glutathione S- } \\
\text { transferase }\end{array}$ & $\underline{\text { AGAP004382 }}$ \\
\hline COEAE1G & Carboxylesterases & $\underline{\text { AGAP006700 }}$ \\
\hline COEJHE1E & Carboxylesterases & $\underline{\text { AGAP005833 }}$ \\
\hline COEunkn & Carboxylesterases & $\underline{\text { AGAP011509 }}$ \\
\hline COEAE1F & Carboxylesterases & $\underline{\text { AGAP006227 }}$ \\
\hline COEAE7G & Carboxylesterases & $\underline{\text { AGAP006728 }}$ \\
\hline COEBE2O & Carboxylesterases & $\underline{\text { AGAP001101 }}$ \\
\hline COEBE4C & Ceroxidase & $\underline{\text { AGAP005370 }}$ \\
\hline HPX7 & $\underline{\text { AGAP004036 }}$ \\
\hline HPX5A & $\underline{\text { AGAP000051 }}$ \\
\hline SP21408 & AGAP004015 \\
\hline
\end{tabular}


by cross hybridization of probes to multiple genes can not be excluded. Therefore qPCR was performed to validate the results from the genes found over-expressed in both sexes.

Table 4 Percentage similarity between cDNA probes on An. gambiae 'detox chip' and the An. funestus genes

\begin{tabular}{|l|l|l|l|}
\hline $\begin{array}{l}\text { An. funestus gene } \\
\text { name }\end{array}$ & $\begin{array}{l}\text { An. gambiae gene } \\
\text { name }\end{array}$ & $\begin{array}{l}\text { Percentage DNA } \\
\text { similarity (\%) }\end{array}$ & $\begin{array}{l}\text { An. funestus gene } \\
\text { accession number }\end{array}$ \\
\hline & & & \\
\hline COI & COI & 50.3 & AY423059.1 \\
\hline CYP6M1 & CYP6M1 & 79.4 & AY987356.1 \\
\hline CYP6M8 & CYP6M2 & 49.4 & AY729660.1 \\
\hline${ }^{*}$ CYP6P4 & CYP6P4 & 75.0 & EU852651.1 \\
\hline CYP9J11 & CYP9J5 & 52.3 & AY729662.1 \\
\hline CYP9J12 & CYP9J3 & 43.5 & AY729663.1 \\
\hline CYP6P9 & CYP6P3 & 81.0 & EU450763 \\
\hline CYP6P13 & CYP6P3 & 81.0 & EF152577 \\
\hline CYP6M7 & CYP6M3 & 54.1 & AY729660.1 \\
\hline
\end{tabular}

* Indicates gene that did not produce any signal on the array

\subsection{Validation}

Quantitative PCR (qPCR) was used to validate the microarray results for the three genes over-expressed in both sexes. The up-regulation of $C Y P 6 P 9$ and $C O I$ in the resistant FUMOZ-R strain in both males and females is presented in Figure 3A and Figure 3B respectively. The resistant males showed a fold change of 51 for the CYP6P9 gene, 15 for CYP6P13 and one for COI when qPCR analysis was performed. The females also showed the highest fold change in CYP6P9 (67), followed by CYP6P13 (8) and 4 for the COI gene. 


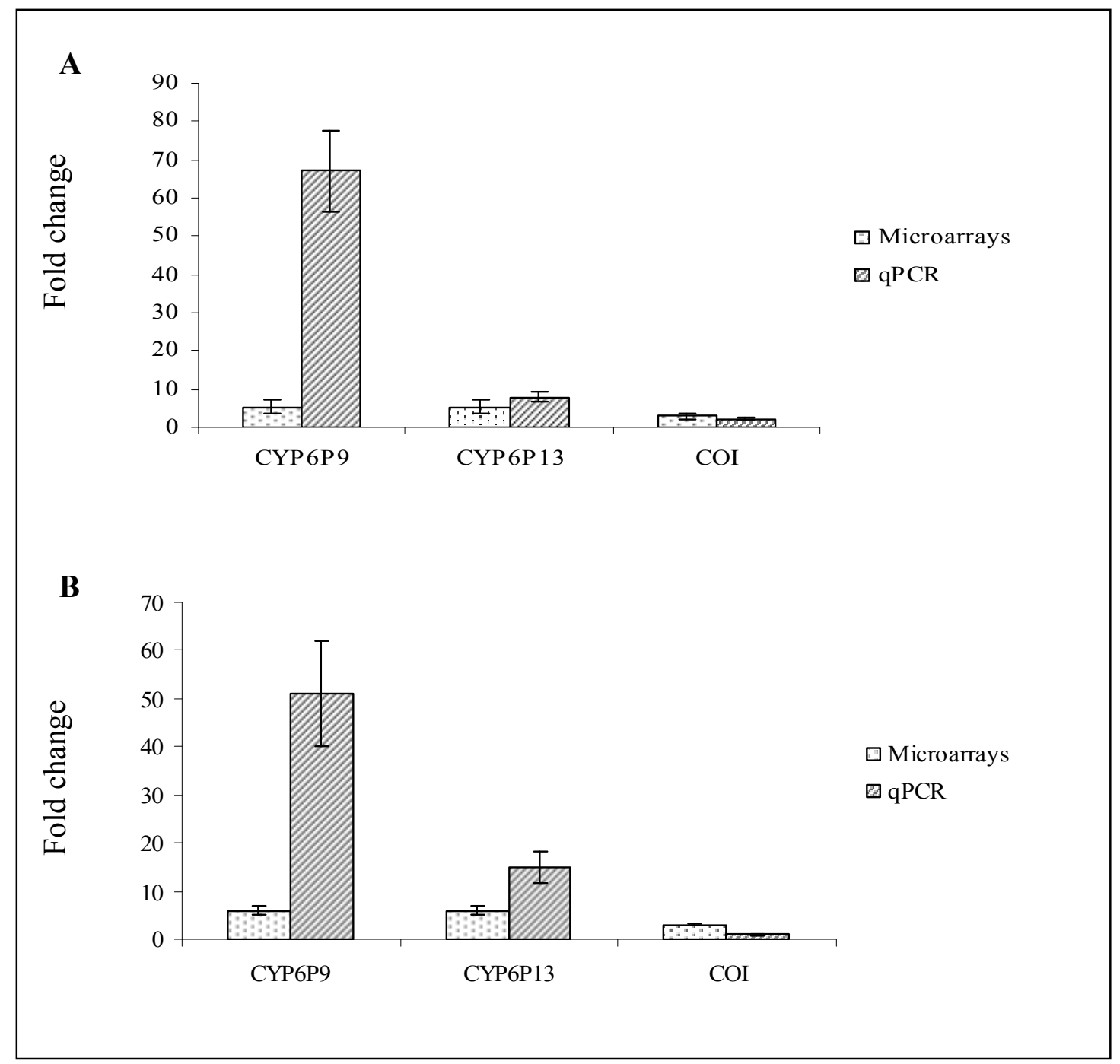

Figure 3 Comparison of qPCR and microarray results for $C Y P 6 P 9, C Y P 6 P 13$ and COI genes in females (A) and males (B).

Comparing the fold over-expression between the qPCR and microarray analysis of the three genes within each sex shows that only CYP6P13 and COI (females) were statistically similar (Figure 3). However each gene is over-expressed in the resistant strain in both males and females although at different levels. One of the reasons for this could be due to the effects of the low stringency hybridization conditions for microarray analysis and this could affect fold over-expression values. The sequence of the probes 
present on the array for each gene is different to the sequence of the primers designed for the CYP6P9 and COI genes for the An. funestus samples. This could be another contributing factor to the differences seen.

Two sets of primers were designed for the CYP6M7 gene based on sequence information from the partial sequence of this An. funestus gene [18] (Table 1). However amplification of the product was unsuccessful for both primers even after numerous attempts.

\section{Discussion}

Gene expression in three day old An. funestus females and males was determined using the An. gambiae 'detox chip' developed by David et al. [11]. This study used crossspecies (heterologous) hybridization of the An. funestus samples to an An. gambiae microarray platform due to the fact that unlike An. gambiae, a fully sequenced genome for An. funestus is currently unavailable. Many studies have successfully evaluated gene expression using non species-specific arrays due to lack of availability of arrays. Moody et al. [28] used human microarrays to study the gene expression in pigs. They found that the reproducibility of microarray hybridization of pig cDNA to human microarrays was high. Cross-species hybridization has also been conducted on rhesus macaque monkeys using a human high-density Affymetrix oligonucleotide array [29]. These results confirmed that a large number of genes were differentially expressed, thereby validating the use of cross-species hybridizations for nonhuman primate studies. Adjaye et al. [30] used human and bovine fetal brain target samples on a human cDNA microarray. Differentially expressed genes were obtained and the study proved that using tissues from 
across species to identify co-expressed orthologous genes on a human microarray platform is possible.

The An. gambiae 'detox chip' has been successfully used to determine the transcriptional analysis of pyrethroid resistance in An. stephensi [17] and An. arabiensis [16]. This is the first study to employ microarrays to determine the genetic basis of pyrethroid resistance in An. funestus. The heterologous hybridization approach was used successfully in this study and approximately $90 \%$ probes were detected. Three genes were differentially expressed in both sexes, CYP6M7, CYP6P9 and COI; COI, CYP6P9 and its duplicate gene CYP6P13, were confirmed to be over-expressed using qPCR analysis. Although statistically the gene expression for the COI gene is different between the two methods for the males, the gene was still differentially expressed in the resistant strain. Although the over-expression of $C O I$ is not significantly high, the role of this gene needs to be investigated.

The fact that CYP6M7 could not be amplified from An. funestus mRNA could possibly imply that it is a pseudogene. However, the lower hybridization stringencies can result in hybridization of another closely related P450 gene to the CYP6M7 probe. This hypothesis can only be validated when a full genome of An. funestus is available. Wondji et al. [19] also attempted to amplify the CYP6M7 gene using a different primer set from the ones used in this study and also failed to obtain amplicons. The CYP6M7 gene needs to be further investigated. 
The CYP6P9 gene has been implicated in playing a role in insecticide resistance in $A n$. funestus. In 2008, Amenya et al. [31] found the CYP6P9 gene to be over-expressed in the egg and adult stages of a pyrethroid resistant laboratory strain (FUMOZ-R) originating from southern Mozambique. Wondji et al. [32] identified a quantitative trait locus (QTL) associated with pyrethroid resistance in the same An. funestus strain. He found that these QTL markers contained a cluster of P450 genes including CYP6P9 and that the chromosomal position of CYP6P9 is associated with permethrin resistance. In 2009 the same author [19] reported that the CYP6P9 gene was 25 times over-expressed in the FUMOZ-R strain in females and that it was tandemly duplicated and this was suggested to contribute to insecticide resistance. Interestingly the CYP6P3 (An. gambiae ortholog) was also found to be differentially expressed (2.82-fold) in field caught An. gambiae adults from Ghana [15]. The CYP6P3 gene was also found at significantly high levels (2.6-fold) in An. arabiensis adults from Cameroon [16].

The observation that additional genes were up-regulated in males than in females in the FUMOZ-R strain was surprising given that resistance is higher in females than males of this strain [25]. It is possible that these 21 additional differentially expressed genes are unrelated to the resistance phenotype. It is interesting to note that several of them are putatively involved in the oxidative stress response (superoxide dismutases (SOD) [33; 34; 35], thioredoxins (TRX) [36], glutathione-S-transferases (GSTs) [37; 38; 39].

Eighteen probes did not hybridize to the RNA target. A large portion of those probes (38\%), belong to the COE group with $28 \%$ from the P450 family. This could be due to 
the reduced sequence similarity between An. gambiae and An. funestus and also these genes may be present in the larval stages of the mosquito life cycle and not in the adult stage. Surprisingly two P450 genes, CYP6P4 and CYP6P1, which were significantly differentially expressed in a study by Wondji et al. [19], did not hybridize to the array. The CYP6P1 and CYP6P4 genes have been shown to have amino acid identities to that of An. gambiae, $82 \%$ and $89 \%$ respectively on small partial sequences analysis [18]. It is unknown why these genes did not hybridize to the slide. This needs to be investigated further.

\section{Conclusions}

The An. gambiae 'detox chip' provided valuable information in identifying potential genes involved in insecticide resistant in An. funestus. We acknowledge the fact that heterologous hybridization is most likely an under representation of the detoxifying genes that are differentially expressed, but it is currently the only tool available to use to screen multiple probes at once. This is a useful and an inexpensive alternative given that the development of a species-specific array will require genome sequencing of the specific species to be investigated and a An. funestus genome was not available at the time. This information will ultimately be used to understand the underlying mechanisms involved in resistance of this important malaria vector and hence aid in the control of effective resistant management. 


\section{Acknowledgements}

This study was supported by funding from the National Research foundation (NRF), the Carnegie funding, the National Health Laboratory Service Research Trust (NHLS-RT) awarded to LLK.

\section{References}

[1] WHO, World malaria report, 2008.

http://apps.who.int/malaria/wmr2008/malaria2008.pdf

[2] WHO, Malaria epidemics, forecasting, prevention, early detection and control-from policy to practise, Report of an informal consultation, Leysin 8-10 December, 2003. WHO/HLT/ MAL/2004. 2004, pp. 1098.

[3] M. Coetzee, D.W.K. Horne, B.D. Brooke, R.H. Hunt, DDT, dieldrin and pyrethroid insecticide resistance in African malaria vector mosquitoes: an historical review and implications for future malaria control in southern Africa, S. Afr. J. Sci. 95 (1999) 215218.

[4] H. Ranson, H. Abdallah, A. Badolo, W.M. Guelbeogo, C.K. Hinzoumbé, E.Y. Kalnoné, N.F. Sagnon, F. Simard, M. Coetzee, Insecticide resistance in Anopheles gambiae: data from the first year of a multi-country study highlight the extent of the problem, Malar J. 8:299 (2009). 
[5] K. Hargreaves, R.H. Hunt, B.D. Brooke, J. Mthembu, M.M. Weeto, T.S. Awolola, M. Coetzee, Anopheles arabiensis and An. quadriannulatus resistance to DDT in South Africa, Medical and Veterinary Entomology. 17 (2003) 417-422.

[6] J.C. Mouatcho, G. Munhenga, K. Hargreaves, B.D. Brooke, M. Coetzee, L.L. Koekemoer, Pyrethroid resistance in a major African malaria vector Anopheles arabiensis from Mamfene, northern Kwazulu-Natal, South Africa, S. Afr. J. Sci. 105 (2009) 127131.

[7] K. Hargreaves, L.L. Koekemoer, B.D. Brooke, R.H. Hunt, J. Mthembu, M. Coetzee, Anopheles funestus resistant to pyrethroid insecticides in South Africa, Medical and Veterinary Entomology. 14 (2000) 181-189.

[8] B.D. Brooke, G. Kloke, R.H. Hunt, L. L. Koekemoer, E.A. Temu, M.E. Taylor, G. Small, J. Hemingway, M. Coetzee, Bioassay and biochemical analysis of insecticide resistance in southern African Anopheles funestus (Diptera: culicidae), Bull. Entomol. Res. 91 (2001) 265-272.

[9] W.G. Brogdon, J.C. McAllister, Insecticide resistance and vector control, Emerging Infect. Dis. 4 (1998) 605-613. 
[10] N. Liu, Q. Xu, F. Zhu, L. Zhang, Pyrethroid resistance in mosquitoes, Insect Sci. 13 (2006) 159-166.

[11] J.P. David, C. Strode, J. Vontas, D. Nikou, A. Vaughan, P.M. Pignatelli, C. Louis, J. Hemingway, H. Ranson, The Anopheles gambiae detoxification chip: A highly specific microarray to study metabolic-based insecticide resistance in malaria vectors, Proc. Natl. Acad. Sci. U. S. A. 102 (2005) 4080-4084.

[12] R.F. Djouaka, A.A. Bakare, O.N. Coulibaly, M.C. Akogbeto, H. Ranson, J. Hemingway, C. Strode, Expression of the cytochrome P450s, CYP6P3 and CYP6M2 are significantly elevated in multiple pyrethroid resistant populations of Anopheles gambiae s.s. from Southern Benin and Nigeria, BMC Genomics. 9: 538 (2008).

[13] T.S. Awolola, O.A. Oduola, C. Strode, L.L. Koekemoer, B.D. Brooke and H. Ranson, Evidence of multiple pyrethroid resistance mechanisms in the malaria vector Anopheles gambiae sensu stricto from Nigeria, Trans. R. Soc. Trop. Med. Hyg. 103 (2009) 1139-1145.

[14] P. Müller, M.J. Donnelly, H. Ranson, Transcription profiling of a recently colonised pyrethroid resistant Anopheles gambiae strain from Ghana, BMC Genomics. 8:36 (2007).

[15] P. Müller, E. Warr, B.J. Stevenson, P.M. Pignatelli, J.C. Morgan, A. Steven, A.E. Yawson, S.N. Mitchell, H. Ranson, J. Hemingway, M.J.I. Paine, M.J. Donnelly, Field- 
caught permethrin-resistant Anopheles gambiae over-express CYP6P3, a P450 that metabolises pyrethroids. Plos Genet. 4:e1000286 (2008b).

[16] P. Müller, M. Chouaïbou, P. Pignatelli, J. Etang, E.D. Walker, M.J. Donnelly, F. Simard H. Ranson, Pyrethroid tolerance is associated with elevated expression of antioxidants and agricultural practice in Anopheles arabiensis sampled from an area of cotton fields in Northern Cameroon, Mol. Ecol. 17 (2008a) 1145-1155.

[17] J. Vontas, J-P. David, D. Nikou, C. Louis, J. Hemingway, G.K. Christophides, H. Ranson, Transcriptional analysis of insecticide resistance in Anopheles stephensi, using cross species microarray hybridization, Insect Mol. Biol. 16 (2007) 315-324.

[18] D.A. Amenya, L.L. Koekemoer, A. Vaughan, J.C. Morgan, B.D. Brooke, R.H. Hunt, H. Ranson, J. Hemingway, M. Coetzee, Isolation and sequence analysis of P450 genes from a pyrethroid resistant colony of the major malaria vector Anopheles funestus, DNA Sequence. 16 (2005) 437-445.

[19] C.S. Wondji, H. Irving, J. Morgan, N.F. Lobo, F.H. Collins, R.H. Hunt, M. Coetzee, J. Hemingway, H. Ranson, Two duplicated P450 genes are associated with pyrethroid resistance in Anopheles funestus, a major malaria vector, Genome Res. 19 (2009) 452459. 
[20] R.H. Hunt, B.D. Brooke, C. Pillay, L.L. Koekemoer, M. Coetzee, Laboratory selection for and characteristics of pyrethroid resistance in the malaria vector Anopheles funestus, Medical and Veterinary Entomology. 19 (2005) 271-275.

[21] G.K. Smyth, Limma: linear models for microarray data, in: R. Gentleman, V.J. Carey, W. Huber, R.A. Irizarry, S. Dudoit (Eds), Bioinformatics and Computational Biology Solutions Using R and Bioconductor (Statistics for Biology and Health). Springer, New York, 2005. pp. 397-420.

[22] M.E. Ritchie, J. Silver, A. Oshlack, J. Silver, M. Holmes, D. Diyagam, A. Holloway, G.K. Smyth, A comparison of background correction methods for two-colour microarrays, Bioinformatics. 23:20 (2007) 2700-2707.

[23] G.K. Smyth, T.P. Speed, Normalization of cDNA microarray data, Methods. 31:4 (2003) 265-273.

[24] G.K. Smyth, Linear models and empirical Bayes methods for assessing differential expression in microarray experiments, Statistical Applications in Genetics and Molecular Biology. 3:1 (2004).

[25] R. Christian, B. Spillings, S.T. Matambo, M. Coetzee, L.L. Koekemoer, The effect of age on pyrethroid resistance and gene expression of two duplicate P450s in a major African malaria vector, Anopheles funestus, Malar. J. (submitted). (2010). 
[26] T.S. Matambo, M.J.I. Paine, M. Coetzee, L.L. Koekemoer, Sequence characterization of cytochrome P450 (CYP6P9) in pyrethroid resistant and susceptible Anopheles funestus (Diptera: Culicidae), Genet. Mol. Res. 9:1 (2010) 554-564.

[27] M.W. Pfaffl, A new mathematical model for relative quantification in real-time RTPCR, Nucleic Acids Res. 29: 45 (2001).

[28] D.E. Moody, Z. Zou, L. McIntyre, Cross-species hybridization of pig RNA to human nylon microarrays, BMC Genomics. 3:27 (2002).

[29] J.D. Chismar, T. Mondala, H.S. Fox, E. Roberts, D. Langford, E. Masliah, D.R. Salomon, S.R. Head, Analysis of result variability from high-density oligonucleotide arrays comparing same-species and cross-species hybridizations, Biotechniques. 33 (2002) 516-518.

[30] J. Adjaye , R. Herwig, D. Herrmann, W. Wruck, A. Benkahla, T.C. Brink, M. Nowak, J.W. Carnwath, C. Hultschig, H. Niemann, H. Lehrach, Cross-species hybridisation of human and bovine orthologous genes on high density cDNA microarrays, BMC Genomics. 5: 83 (2004).

[31] D.A. Amenya, R. Naguran, T-C.M. Lo, H. Ranson, B.L. Spillings, O.R. Wood, B.D. Brooke, M. Coetzee, L.L. Koekemoer, Over-expression of a cytochrome P450 (CYP6P9) 
in a major African malaria vector, Anopheles funestus, resistant to pyrethroids, Insect Molec Biol. 17:1 (2008) 19-25.

[32] C.S. Wondji, J. Morgan, M. Coetzee, R. Hunt, K. Steen, W. IV Black, J. Hemingway, H. Ranson, Mapping a Quantitative Trait Locus (QTL) conferring pyrethroid resistance in the African malaria vector Anopheles funestus, BMC Genomics. $8: 34$ (2007).

[33] P. Chary, D. Dillon, A.L. Schroeder, D.O. Natvig, Superoxide dismutase (sod-1) null mutants of Neurospora crassa: oxidative stress sensitivity, spontaneous mutation rate and response to mutagens, Genetics. 137 (1994) 723-730.

[34] D.J. Jamieson, S.L. Rivers, D.W. Stephen, Analysis of Saccharomyces cerevisiae proteins induced by peroxide and superoxide stress, Microbiology. 140 (1994) 32773283.

[35] N.S. Park, K.S. Lee, H.D. Sohn, D.H. Kim, S.M. Lee, E. Park, I. Kim, Y.H. Je, B.R. Jin, Molecular cloning, expression, and characterization of the $\mathrm{Cu}, \mathrm{Zn}$ superoxide dismutase (SOD1) gene from the entomopathogenic fungus Cordyceps militaris, Mycologia. 97:1 (2005) 130-138. 
[36] H. Bauer, S.M. Kanzok, R.H. Schirmer Thioredoxin-2 but not thioredoxin-1 is a substrate of thioredoxin peroxidase-1 from Drosophila melanogaster, J. Biol. Chem. 277 (2002) 17457-17463.

[37] S. Zou, S. Meadows, L. Sharp, L.Y. Jan, Y.N. Jan, Genome-wide study of aging and oxidative stress response in Drosophila melanogaster, Proc. Natl. Acad. Sci. U. S. A. 97 (2000) 13726-13731.

[38] S.P. Singh, J.A. Coronella, H. Benes, B.J. Cochrane, P. Zimniak, Catalytic function of Drosophila melanogaster glutathione S-transferase DmGSTS1-1 (GST-2) in conjugation of lipid peroxidation end products, Eur. J. Biochem. 268 (2001) 2912-2923.

[39] Y. Ding, F. Ortelli, L.C. Rossiter, J. Hemingway, H. Ranson, The Anopheles gambiae glutathione transferase supergene family: annotation, phylogeny and expression profiles, BMC Genomics. 4:35 (2003). 